\title{
Hubungan antara Kepadatan Populasi Kutu Daun Persik (Myzus persicae Sulz.) dan Tingkat Kerusakan Daun dengan Kehilangan Hasil Cabai Merah (Capsicum annuum L.)
}

\author{
Sudarjat \\ Jurusan Hama dan Penyakit Tumbuhan, Fakultas Pertanian, \\ Universitas Padjadjaran, Jatinagor, Bandung 40600 \\ Korespondensi : ajat_proteksi@yahoo.com
}

\begin{abstract}
The Relationship between Green Peach Aphid (Myzus persicae Sulz.) Population Density, Leaf Damage and Red Pepper (Capsicum annuum L.) Yield Loss
\end{abstract}

A research to determine relationship between the green peach aphid population density, the leaf damage and the red pepper yield loss has been carried out in the plastic house. Eight levels of $M$. persicae population density $(0,2,4,8,16,32,64$, and 128 insect/plant) were infested at the first growth and the first flowering phase of red pepper respectively. The results of this experiment showed that the $M$. persicae population density and the leaf damage levels caused by $M$. persicae had a close relationship with the red pepper yield loss. The relationship between the $M$. persicae population density $(X)$ and the the yield loss $(Y)$ was based on the equation $Y=19.1865+0.3568 X$ with determination coefficient $R^{2}=0.8724$ and damage coefficient $d=0.8721 \mathrm{~g} /$ insect; and $Y=19.8504+0.3181 X \quad\left(R^{2}=0.6218\right.$ and $d=0.7179 \mathrm{~g} /$ insect) when $M$. persicae were infested on the first growth and the first flowering phase of red pepper respectively. When $M$. persicae were infested on the first growth phase, the relationship between the leaf damage and the yield loss was based on the equation $Y=25.93+64.51 X_{1}+0.26 X_{2}-2.27 X_{3}\{(Y=$ yield loss (\%); $X_{1}=$ leaf damage (\%); $X_{2}=$ first population density (insect/plant) and $X_{3}=$ observation time (week after infested) $\}$ with $R^{2}=0.7875$ and damage coefficient $=1.577 \mathrm{~g} / \%$ leaf damage), while when $M$. persicae were infested on the first flowering phase the equation was $Y=25.59+1164.87 X_{1}+0.08 X_{2}-4.60 X_{3}$, with $R^{2}=0.7918$ and damage coefficient $=3.72 \mathrm{~g} / \%$ leaf damage.

Key words: Myzus persicae, population density, leaf damage, Capsicum annuum

\begin{abstract}
ABSTRAK
Penelitian rumah plastik ini bertujuan untuk mengetahui hubungan antara kepadatan populasi hama kutu daun persik (Myzus persicae Sulz.), tingkat kerusakan daun dan kehilangan hasil cabai merah (Capsicum annuum). Delapan taraf kepadatan populasi $M$. persicae $(0,2,4,8,16,32,64$, dan 128 ekor / tanaman) masing-masing diinfestasikan pada tanaman cabai pada fase pertumbuhan awal dan fase pembungaan awal. Hasil penelitian menunjukkan bahwa populasi $M$. persicae dan tingkat kerusakan daun oleh hama tersebut berhubungan erat dengan kehilangan hasil cabai merah. Pada tanaman yang diinfestasi $M$. persicae saat fase pertumbuhan awal, hubungan antara kepadatan populasi $(X)$ dengan kehilangan hasil $(Y)$ mengikuti persamaan garis regresi $Y=19,1865+0,3568 X$ dengan keefektifan menduga sebesar $73,85 \%$ dan koefisien kerusakan sebesar 0,8724 g/ekor. Persamaan garis untuk tanaman yang diinfestasi $M$. persicae saat fase pembungaan awal adalah $Y=19,8504+$
\end{abstract}


0,3181X dengan keefektifan menduga 62,18 \% dan koefisien kerusakan 0,7179 g/ekor. Hubungan antara tingkat kerusakan daun dengan kehilangan hasil pada tanaman cabai yang diinfestasi $M$. persicae saat fase pertumbuhan awal mengikuti persamaan garis regresi $Y=25,93+64,51 X_{1}+0,26 X_{2}-2,27 X_{3}\{(Y=$ kehilangan hasil (\%); $X_{1}=$ tingkat kerusakan daun oleh $M$. persicae (\%); $X_{2}=$ populasi awal $M$. persicae (ekor/tanaman) dan $X_{3}=$ waktu pengamatan (minggu setelah infestasi) dengan keefektifan menduga 78,75 \% dan koefisien kerusakan 1,577 g/\% kerusakan daun. Persamaan garis untuk tanaman cabai yang diinfestasi $M$. persicae saat fase pembungaan awal adalah $Y=25,59+1164,87 X_{1}+0,08 X_{2}-4,60 X_{3}$, dengan keefektifan menduga 79,18\% dan koefisien kerusakan 3,72 g/\% kerusakan daun.

Kata kunci: Myzus persicae, kepadatan populasi, kerusakan daun, Capsicum annuum

\section{PENDAHULUAN}

Tanaman cabai merah (Capsicum annuum L.) merupakan salah satu tanaman hortikultura yang mempunyai nilai ekonomi penting yang perlu ditingkatkan produksinya. Usaha peningkatan produksi cabai merah telah dilakukan dengan perluasan areal dan pengusahaan yang intensif meliputi penggunaan bibit unggul, pemupukan, pengaturan pemberian air, cara bercocok tanam yang lebih baik, serta pengendalian organisme pengganggu tanaman, termasuk serangga hama yang menyerang tanaman cabai.

Salah satu hama penting yang menyerang tanaman cabai adalah kutu daun persik (Myzus persicae Sulz.) (Kalshoven, 1981), Serangga hama ini ditemukan pada bagian bawah daun dan mengisap cairan sel daun sehingga daun berwarna kekuningan, pertumbuhan tanaman terhambat, daun berkeriput, layu, kemudian mati (Hill, 1997). M. persicae juga bertindak sebagai vektor penyakit virus (Lamb, 1974), bahkan menurut Daly et al. (1978), M. persicae dapat menjadi vektor lebih dari 100 jenis virus.

Berbagai cara telah ditempuh untuk mengendalikan $M$. persica dan berdasarkan Peraturan Pemerintah No. 6 Tahun 1995 pasal 3 ditetapkan bahwa perlindungan tanaman dilaksanakan melalui sistem pengendalian hama terpadu (PHT) yang salah satu komponennya adalah pengendalian berdasarkan ambang ekonomi hama. Ambang ekonomi adalah suatu tingkatan populasi atau kerusakan akibat hama yang menghendaki tindakan pengendalian yang dapat dipertanggungjawabkan secara ekonomi (Carlson, 1971). Jika nilai ambang ekonomi akan digunakan untuk pengambilan keputusan pengendalian, maka penentuan hubungan antara populasi dan tingkat kerusakan dengan kehilangan hasil tanaman mutlak diperlukan (Walker, 1991).

Hubungan antara kepadatan populasi hama atau tingkat kerusakan tanaman akibat hama dengan kehilangan hasil tanaman membentuk model regresi linier $Y=a+b x$, dengan $b$ merupakan nilai koefisien arah regresi yang sama dengan koefisien kerusakan (damage coefficient). Dengan demikian maka koefisien kerusakan adalah angka yang menunjukkan besarnya kehilangan hasil tanaman untuk setiap ekor (individu) hama atau untuk setiap satu satuan (\%) tingkat kerusakan tanaman. Oleh karena kehilangan hasil dalam satuan \% maka berlaku rumus (Norton, 1976: Pedigo 1991; Teng, 1991) : $d=$ b x m, dimana $d$ adalah koefisien kerusakan (kg/ekor hama atau $\mathrm{kg}$ /tingkat kerusakan tanaman, $b$ adalah koefisien arah regresi dan $m$ adalah hasil maksimum pada saat tidak ada hama $(\mathrm{kg})$.

Nilai ambang ekonomi $M$. persicae pada tanaman cabai di Indonesia belum tersedia. Oleh karena itu perlu dilakukan penelitian untuk mencari nilai koefisien kerusakan tanaman cabai merah akibat adanya serangan $M$. persicae, untuk selanjutnya digunakan untuk mencari nilai ambang ekonomi.

\section{BAHAN DAN METODE}

Penelitian dilakukan di rumah plastik Fakultas Pertanian Universitas Padjadjaran di Jatinangor menggunakan metode eksperimen semi lapangan dengan dua seri percobaan. Masing-masing seri percobaan menggunakan Rancangan Acak 
Kelompok yang terdiri atas delapan macam perlakuan dengan empat ulangan.

Pada percobaan pertama, di fase pertumbuhan awal, tanaman cabe diinfestasi dengan masing-masing 0 , 2, 4, 8, 16, 32, 64, dan 128 ekor $M$. persicae per tanaman. Pada percobaan kedua, infestasi kutu persik dengan perlakuan yang sama dilakukan saat tanamana caabai mencapai fase pembungaan. Untuk kedua seri percobaan tersebut, setelah tanaman diinfestasi dengan $M$. persicae, setiap individu tanaman disungkup dengan kain kasa untuk menghindari adanya migrasi hama antar perlakuan. Variabel respons yang diamati adalah perkembangan populasi hama dan tingkat kerusakan daun setiap minggu, serta hasil panen yang dihitung berdasarkan berat total buah bagus yang layak jual dari delapan kali panen.

Perkembangan populasi hama berdasarkan pada jumlah kepadatan populasi hama pada seluruh tanaman setiap minggu, dimulai satu minggu setelah infestasi.

Pengamatan tingkat kerusakan daun dilakukan setiap minggu, dimulai satu minggu setelah infestasi berdasarkan pada :

$$
\mathrm{P}=\frac{\Sigma \mathrm{nv}}{\mathrm{ZN}} \times 100 \%
$$

dimana $\mathrm{P}=$ tingkat kerusakan daun (\%), $\mathrm{n}=$ jumlah daun yang diamati dari tiap katagori serangan yang sama, $\mathrm{v}=$ nilai skala tiap katagori serangan, $\mathrm{Z}$ = skala katagori serangan tertinggi, dan $\mathrm{N}=$ jumlah seluruh daun yang diamati

Nilai katagori serangan (v) didasarkan pada luas daun terserang yaitu $0=$ tidak ada serangan sama sekali, 1 jika $0 \%<\mathrm{X}_{1} \leq 20 \%$ luas daun terserang, 3 jika $20 \%<\mathrm{X}_{3} \leq 40 \%$ luas daun terserang, 5 jika $40 \%<\mathrm{X}_{5} \leq 60 \%$ luas daun terserang, 7 jika $60 \%<\mathrm{X}_{7} \leq 80 \%$ luas daun terserang, dan 9 jika $80 \%<\mathrm{X}_{9} \leq 20 \%$ luas daun terserang.

Data hasil pengamatan dianalisis dengan analisis ragam. Data yang bersifat tidak menyebar normal ditranformasi dahulu sebelum dianalisis. Data kehilangan hasil akan digunakan untuk mencari hubungan :

$$
y=f(i)
$$

diamana $\mathrm{y}=$ kehilangan hasil, $\mathrm{i}=$ populasi $M$. persicae atau tingkat kerusakan daun akibat serangan M. persicae.

Bentuk hubungan tersebut dapat diganti dengan model persamaan regresi :

$$
\mathrm{Yi}=\beta_{0}+\beta_{1} \mathrm{X}_{\mathrm{i}}+\varepsilon_{\mathrm{i}}
$$

Untuk menguji hipotesis : $H_{0}: \beta_{1}=0$ lawan $H_{1}: \beta_{1}$ $\neq 0$ dilakukan dengan metode analisis varian (Draper \& Smith, 1992)

Jika :

Fh $<$ F.05 - $\longrightarrow$ terima $\mathrm{H}_{0}: \beta_{1}=0$ artinya persamaan regresi di atas tidak dapat digunakan sebagai penduga nilai $\mathrm{Y}$ berdasarkan nilai-nilai $\mathrm{X}$ yang diketahui.

Fh $>$ F.05 - $\longrightarrow$ tolak $\mathrm{H}_{0}: \beta_{1} \neq 0$ artinya persamaan regresi di atas dapat digunakan sebagai penduga nilai $\mathrm{Y}$ berdasarkan nilai-nilai $\mathrm{X}$ yang diketahui.

Tabel 1. Hasil dan kehilangan hasil cabai merah akibat infestasi $M$. persicae pada fase pertumbuhan awal

\begin{tabular}{ccc}
\hline $\begin{array}{c}\text { Infestasi } \boldsymbol{M} \text {. persicae } \\
\text { (ekor/tanaman) }\end{array}$ & $\begin{array}{c}\text { Hasil Buah Bagus } \\
(\mathrm{g})\end{array}$ & $\begin{array}{c}\text { Kehilangan Hasil } \\
(\%)\end{array}$ \\
\hline 0 & $244,53 \mathrm{a}$ & 0,00 \\
2 & $204,72 \mathrm{ab}$ & 16,28 \\
4 & $188,94 \mathrm{ab}$ & 22,73 \\
8 & $174,80 \mathrm{abc}$ & 28,52 \\
16 & $156,74 \mathrm{abc}$ & 35,90 \\
32 & $150,60 \mathrm{abc}$ & 38,41 \\
64 & $145,97 \mathrm{bc}$ & 40,30 \\
128 & $93,00 \mathrm{c}$ & 61,97 \\
\hline
\end{tabular}




\section{HASIL DAN PEMBAHASAN}

\section{Hasil Cabai Merah}

Pada Tabel 1 dan Tabel 2 tampak bahwa kepadatan populasi $M$. persicae berpengaruh terhadap hasil buah bagus, baik untuk infestasi $M$. persicae pada fase pertumbuhan awal maupun pada fase pembungaan awal tanaman cabai.

Keterangan : Angka rata-rata yang diikuti oleh huruf yang sama pada kolom yang sama, tidak berbeda nyata menurut Uji Jarak Berganda Duncan pada taraf nyata $5 \%$.

$M$. persicae yang diinfestasikan ke tanaman cabai pada fase pertumbuhan awal dapat menurunkan berat cabai yang dihasilkan. Infestasi $M$. persicae 64 dan 128 ekor/tanaman menyebabkan berat buah yang dihasilkan sangat rendah dan berbeda nyata dengan kontrol, dengan kehilangan hasil pada kedua perlakuan tersebut masing-masing sebanyak 40,30 \% dan 61,97\%. Rendahnya berat buah cabai yang dihasilkan, selain akibat dari jumlah buah yang sedikit juga ukuran buah relatif kecil dibandingkan dengan buah cabai yang dihasilkan pada perlakuan kontrol. Tingkat kehilangan hasil tertinggi didapatkan pada tanaman cabai yang diinfestasi $M$. persicae 128 ekor/tanaman yaitu sebesar $61,97 \%$.

Tanaman cabai yang diinfestasi $M$. persicae pada fase pembungaan awal juga menghasilkan berat buah yang lebih rendah dibandingkan dengan kontrol, Berat buah tanaman yang diinfestasi dengan
16, 32, 64, dan 128 ekor/tanaman berbeda nyata dengan kontrol. Kehilangan hasil tertinggi juga terjadi pada tanaman yang diinfestasi $M$. persicae 128 ekor/tanaman yaitu sebesar 54,25\%.

Kedua hasil percobaan tersebut membuktikan bahwa $M$. persicae yang menyerang tanaman cabai baik yang mulai menyerang pada fase pertumbuhan awal maupun fase pembungaan awal, sama-sama dapat mengakibatkan kehilangan hasil yang cukup besar.

\section{Hubungan Antara Kepadatan Populasi M. persicae Dengan Kehilangan Hasil Cabai Merah}

Untuk menguji ada tidaknya hubungan antara kepadatan populasi $M$. persicae $(\mathrm{X})$ dengan persentase kehilangan hasil cabai merah (Y) maka dilakukan analisis regresi. Hasil analisis untuk infestasi $M$. persicae pada fase pertumbuhan awal didapatkan persamaan garis regresi $Y=19,1865+$ 0,3568 $X$ dengan koefisien korelasi $R=0,8594$ yang menunjukkan keeratan hubungan antara keduanya cukup kuat. Koefisien arah (b) yang besarnya = 0,3568 adalah koefisien kerusakan yang artinya penambahan satu ekor $M$. persicae dapat menyebabkan kehilangan hasil sebesar 0,3568 \% (Gambar 1). Pada percobaan ini hasil maksimum pada saat tidak ada hama $M$. persicae (m) pada perlakuan kontrol adalah 244,53 gram, maka koefisien kerusakan (d) besarnya setara dengan 0,3568:100 x 244,53 g = 0,8724 g/ekor.

Berdasarkan analisis ragam F-hitung

Tabel 2. Rata-rata Hasil dan Kehilangan Hasil Cabai Merah Akibat Infestasi M. persicae pada Fase Pembungaan Awal

\begin{tabular}{|c|c|c|}
\hline $\begin{array}{c}\text { Infestasi M. persicae } \\
\text { (ekor/tanaman) }\end{array}$ & $\begin{array}{c}\text { Hasil Buah Bagus } \\
(\mathrm{g})\end{array}$ & $\begin{array}{c}\text { Kehilangan Hasil } \\
(\%)\end{array}$ \\
\hline 0 & $225,68 \mathrm{a}$ & 0,00 \\
\hline 2 & $198,72 \mathrm{ab}$ & 11,95 \\
\hline 4 & $177,31 \mathrm{abc}$ & 21,43 \\
\hline 8 & $157,21 \mathrm{abc}$ & 30,34 \\
\hline 16 & 141,68 bc & 37,22 \\
\hline 32 & 133,72 bc & 40,75 \\
\hline 64 & 127,19 bc & 43,64 \\
\hline 128 & 103,25 c & 54,25 \\
\hline
\end{tabular}

Keterangan: Angka rata-rata yang diikuti oleh huruf yang sama pada kolom yang sama, tidak berbeda nyata menurut Uii Jarak Berganda Duncan pada taraf nvata $5 \%$. 
memperlihatkan perbedaan yang nyata yang menunjukkan bahwa persamaan garis regresi tersebut dapat digunakan untuk meramal kehilangan hasil cabai merah berdasarkan kepadatan populasi $M$. persicae yang diketahui. Koefisien determinasi yang dari hasil analisis adalah $\mathrm{R}^{2}=0,7385$; artinya keragaman kehilangan hasil cabai dapat diterangkan oleh keragaman kepadatan populasi $M$. persicae sebesar 73,85 \%, sedangkan sisanya sebesar 26,15\% oleh faktor-faktor lain yang tidak diketahui.

Persamaan garis regresi untuk infestasi $M$. persicae pada fase pembungaan awal adalah $Y=$
$19,8504+0,3181 X$ dengan koefisien korelasi $R=$ 0,7885 yang menunjukkan keeratan hubungan antara hasil $(Y)$ dan populasi $M$. persicae $(X)$ yang cukup kuat. Koefisien kerusakan adalah sebesar 0,3181:100 x 225,68 g = 0,7179 g ekor (Gambar 2).

Berdasarkan analisis ragam ternyata $\mathrm{F}$ hitung memperlihatkan perbedaan yang nyata. Artinya persamaan garis regresi tersebut dapat digunakan untuk meramal kehilangan hasil cabai merah berdasarkan kepadatan populasi $M$. persicae yang diketahui. Keefektifan menduga $\left(R^{2}\right)$ dari persamaan tersebut sebesar $62,18 \%$.

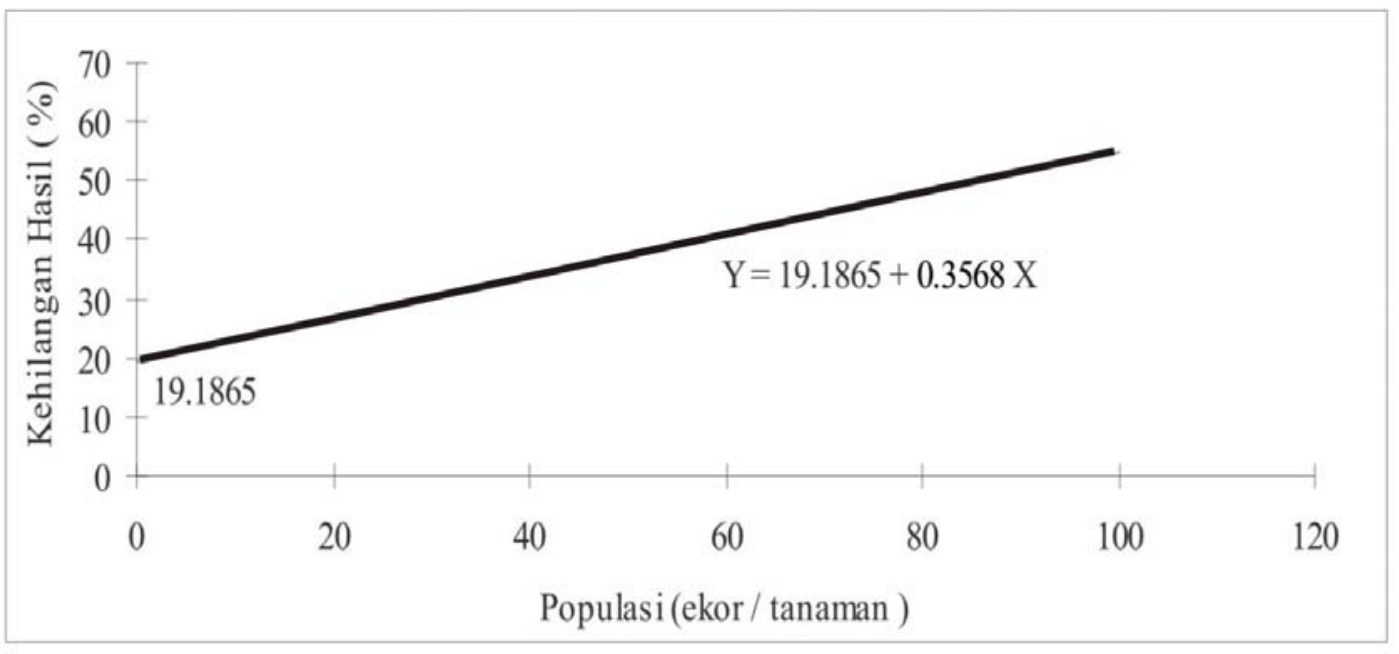

Gambar 1. Hubungan antara kepadatan populasi kutu daun persik dengan kehilangan hasil cabai fase pertumbuhan awal

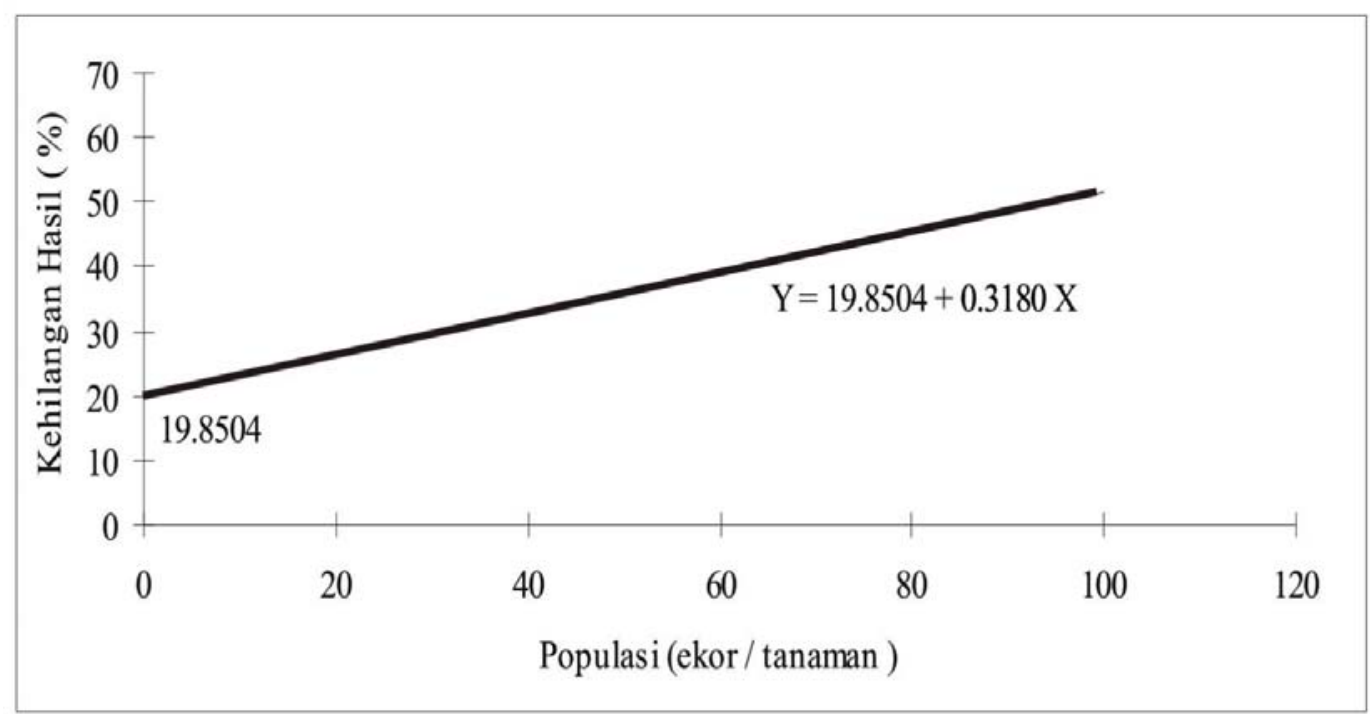

Gambar 2. Hubungan antara kepadatan populasi kutu daun persik dengan kehilangan hasil cabai pada fase pembungaan awal 


\section{Hubungan Antara Tingkat Kerusakan Daun Dengan Kehilangan Hasil Cabai Merah}

Untuk menentukan ada tidaknya hubungan antara tingkat kerusakan daun dengan kehilangan hasil cabai merah dalam percobaan ini cukup sulit karena ternyata perbedaan kepadatan populasi awal tidak berpengaruh nyata terhadap tingkat kerusakan daun sampai dengan empat minggu setelah infestasi. Selain itu, tingkat kerusakan daun sangat dipengaruhi oleh perkembangan kepadatan populasi sehingga tingkat kerusakan daun selalu terus berubah seiring dengan perubahan tingkat kepadatan populasi $M$. persicae dari minggu ke minggu. Oleh karena itu variabel populasi awal dan waktu pengamatan harus dimasukkan ke dalam model persamaan garis regresi sehingga untuk menentukan ada tidaknya hubungan dilakukan analisis regresi berganda.

Hasil analisis regresi berganda antara tingkat kerusakan daun $\left(X_{I}\right)$, populasi awal $\left(X_{2}\right)$ dan waktu kerusakan daun $\left(X_{3}\right)$ itu terjadi dengan kehilangan hasil cabai merah $(Y)$ untuk infestasi $M$. persicae pada fase pertumbuhan awal didapat persamaan garis regresi $Y=25.93+64,51 X_{1}+0,26 X_{2}-2,27 X_{3}$ dengan tingkat keeratan hubungan $R$ sebesar 0,8874 dan koefisien determinasi $R^{2}$ sebesar 0,7875. Untuk mengetahui apakah persamaan garis regresi tersebut mempunyai landasan untuk meramal kehilangan hasil cabai merah berdasarkan tingkat kerusakan daun, populasi awal dan waktu pengamatan, maka koefisien korelasinya harus berbeda nyata.

Berdasarkan analisis ragam ternyata $\mathrm{F}$ hitung memperlihatkan perbedaan yang sangat nyata, artinya hubungan antara tingkat kerusakan daun, populasi awal dan waktu pengamatan dengan kehilangan hasil cabai merah sangat erat. Adanya hubungan yang sangat erat ini membuktikan bahwa persamaan garis regresi tersebut dapat digunakan untuk meramal persentase kehilangan hasil berdasarkan tingkat kerusakan daun cabai akibat serangan $M$. persicae, populasi awal $M$. persicae dan waktu pengamatan. Keefektifan menduga dari persamaan tersebut sebesar $78,75 \%$, dengan koefisien kerusakan sebesar $64,51 / 100$ x 244,53/100 $=1,577$ gram kehilangan hasil untuk setiap satu persen kerusakan daun.

Hasil analisis untuk infestasi $M$. persicae pada fase pembungaan awal, didapat persamaan garis regresi $Y=25,59+1164,87 X_{1}+0,08 X_{2}-4,60 X_{3}\{Y$ $=$ persentase kehilangan hasil (\%); $X_{1}=$ tingkat kerusakan daun oleh $M$. persicae (\%); $X_{2}=$ populasi awal $M$. persicae (ekor / tanaman) dan $\mathrm{X}_{3}=$ waktu pengamatan minggu setelah infestasi) $\}$ dengan koefisien korelasi $R$ sebesar 0,8898 dan koefisien determinasi $R^{2}$ sebesar 0,7918 .

Hasil analisis ragam menunjukkan bahwa Fhitung memperlihatkan perbedaan yang nyata, artinya persamaan garis regresi tersebut dapat digunakan untuk meramal kehilangan hasil cabai merah berdasarkan tingkat kerusakan daun cabai oleh $M$. persicae, populasi awal $M$. persicae dan waktu pengamatan. Keefektifan menduga dari rumus tersebut sebesar 79,18 \%. Koefisien kerusakan sebesar 3,72 gram / persen kerusakan daun.

\section{SIMPULAN}

Kepadatan populasi Myzus persicae dan tingkat kerusakan daun oleh Myzus persicae mempunyai hubungan yang erat dengan kehilangan hasil cabai merah. Pada tanaman cabai yang diinfestasi $M$. persicae saat fase pertumbuhan awal, hubungan antara kepadatan populasi dengan kehilangan hasil mengikuti persamaan garis regresi $Y=19.1865+0.3568 X$ dengan efektivitas menduga sebesar 73,85 \% dan koefisien kerusakan sebesar 0,8724 g/ekor , sedangkan untuk tanaman yang diinfestasi $M$. persicae saat fase pembungaan awal mengikuti persamaan garis $Y=19,8504+0,3181 X$ dengan keefektifan menduga sebesar $62,18 \%$ dan koefisien kerusakan sebesar 0,7179 g / ekor.

Hubungan antara tingkat kerusakan daun dengan kehilangan hasil pada tanaman cabai yang diinfestasi $M$. persicae saat fase pertumbuhan awal mengikuti persamaan garis regresi $Y=25,93+64,51$ $X_{1}+0,26 X_{2}-2,27 X_{3}\left\{\left(Y=\right.\right.$ kehilangan hasil (\%); $X_{1}$ = tingkat kerusakan daun oleh $M$. persicae (\%); $X_{2}=$ populasi awal $M$. persicae (ekor/tanaman) dan $X_{3}=$ waktu pengamatan (minggu setelah infestasi)\} dengan keefektifan menduga sebesar 78,75 \% dan koefisien kerusakan tanaman sebesar 1,577 g/persen kerusakan daun. Untuk tanaman cabai yang diinfestasi $M$. persicae saat fase pembungaan awal mengikuti persamaan garis $Y=25,59+1164,87 X_{1}+$ $0,08 X_{2}-4,60 X_{3}$, dengan keefektifan menduga sebesar 79,18 \% dan koefisien kerusakan sebesar 3,72 $\mathrm{g} /$ persen kerusakan daun.

\section{UCAPAN TERIMAKASIH}

Ucapan terima kasih dan penghargaan yang setinggi-tingginya penulis sampaikan kepada Sdr. 
Ema Budiman dan Eka Purnama, SP yang telah membantu penulis dalam pelaksanaan penelitian ini.

\section{DAFTAR PUSTAKA}

Carlson, G. A. 1971. Economic Aspect of Crop Loss Control at the Farmer Level. FAO Manual of Crop Loss Assessment. Rome.

Daly, H. V., J. T. Doyen, and P. R. Ehrlich. 1978. Introduction to Insect Biology and Diversity. Mc Graw-Hill Kogakusha, Ltd. Tokyo.

Draper, N. dan H. Smith. 1992. Analisis Regresi Terapan. Terjemahan. PT. Gramedia Pustaka Utama. Jakarta.

Hill, D. S. 1997. The Economic Importance of Insects. Chapman \& Hall. London, Weinheim, New York, Tokyo, Melbourne, Madras.
Kalshoven, L. G. E. 1981. Pest of Crops in Indonesia. PT. Ichtiar Baru - Van Hoeve. Jakarta.

Lamb, K. P. 1974. Economic Entomology in the Tropic. Academic Press, Inc. London.

Norton, G. A. 1976. Analysis of decision making in crop protection. Agro-ecosystem 3: 27 - 44.

Pedigo, L. P. 1991. Entomology and Pest Management. Macmillan Publishing Company, New York

Teng, P. S. (ed.). 1991. Crop Loss Assessment and Pest Management. APS Press the American Phytopathological Society St. Paul Minnesota.

Walker, P. T. 1991. Measurement of Insect Populations and Injury in Crop Loss Assessment and Pest Management (Teng, P. S.). APS Press the American Phytopathological Society. St. Paul Minnesota. pp. 19 - 29. 